\title{
Advancement of rotifer culture and manipulation techniques in Europe
}

\author{
Philippe Dhert ${ }^{\mathrm{a}, *}$, Geert Rombaut ${ }^{\mathrm{b}}$, Gede Suantika ${ }^{\mathrm{a}}$, \\ Patrick Sorgeloos ${ }^{\mathrm{a}}$ \\ a Laboratory of Aquaculture and Artemia Reference Center, Ghent University, Rozier 44, \\ B-9000 Gent, Belgium \\ ${ }^{\mathrm{b}}$ Laboratory of Microbial Ecology and Technology, Ghent University, Coupure L 653, B-9000 Gent, Belgium
}

\begin{abstract}
Since no artificial feed formulation for first feeding of marine larval fish has been developed yet, live prey feeding remains essential in commercial marine hatchery operations. Because cultured rotifers are relatively poor in eicosapentaenoic acid (EPA: 20:5n-3) and docosahexaenoic acid (DHA: 22:6n-3), it is essential and therefore common practice to enrich these live prey with emulsions of marine oils. The short-term exposure to oil emulsions results in lipid-encapsulated rotifers with high EPA and DHA levels. However, these rotifers are prone to fast losses of their gut content and show a distortion in their protein/lipid balance. Rather than submerging rotifers in oil emulsions, it is often preferred to use formulated culture diets when medium to low enrichment values are needed in live prey. The use of these diets contributes not only to the filling of the gut of the rotifers with nutrients, it generally creates a more stable entire body composition which is important especially when rotifers are not consumed immediately by the larvae.

New culture techniques for rotifers, such as closed recirculation systems, are offering new possibilities for continuous supplies of high quality rotifers at 10 times higher densities than in batch cultures. The production increase in these systems is explained by the better water quality obtained by the introduction of protein skimmers, ozone treatment, and biological filtration. Although disinfection of rotifers remains a bottleneck, it has been observed that rotifer populations cultured at high densities are not prone to higher bacterial infestation. Also, the problem of unexplained mortalities in batch cultures seems to be partly solved by the introduction of recirculation systems or by bacterial management (introduction of probionts), which allow more reliable rotifer production. (C) 2001 Elsevier Science B.V. All rights reserved.
\end{abstract}

Keywords: Rotifer production; Live feeds; HUFA; DHA; EPA

\footnotetext{
* Corresponding author.
} 


\section{Introduction}

Larviculture, more particularly the start feeding of early larval stages, appears to be the major bottleneck for the industrial upscaling of the culture of fish and crustaceans. Evolutionary, larvae of most fish and crustaceans are fixed on the scheme of motile prey organisms and encounter problems to accept inert/dry diets. Even if they accept the diets, their poor enzymatic activity and non-functional stomach will not allow them to digest the existing formulated diets (Pedersen et al., 1987; Pedersen and Hjelmeland, 1988). Improving the acceptance of dry diets for fish larvae and formulate more digestible and less polluting diets thus still remain a central task for aquaculturists. Before this is achieved, live food (phyto- and zooplanktons) will remain an important food source for the start feeding of early larval stages.

One of the important starter feeds used in larviculture is the marine rotifer $\mathrm{Bra}$ chionus plicatilis. The successful development of commercial farms in the Mediterranean area has been made possible by several improvements in the production techniques of this live food (Candreva et al., 1996; Dehasque et al., 1998).

The nutritional aspects of rotifers have received major attention in larviculture and several commercial products have been launched to increase the lipid and vitamin content in rotifers (Coutteau and Sorgeloos, 1997). Although it is technically possible to produce rotifers of high nutritional value, their quality is often far from optimal due to their low hygienic quality and overall condition (low swimming velocity, low reproduction rate, etc.). In this respect, the microbiology involved in rotifer rearing is getting increased attention (Rombaut et al., 1999).

Surprisingly enough, very few modifications or improvements on the culture techniques of rotifers have been proposed on a commercial scale (Abu-Rezq et al., 1997; Yoshimura et al., 1996) and in general, European hatcheries still rear rotifers in batch systems with little attention for water quality. Among the most frequently reported problems are: (1) the unpredictability of rotifer mass production, (2) the difficulty to manage and harvest large rotifer populations, (3) the difficulty of producing a clean rotifer (free of floccules and safe from a microbial point of view).

Besides the zootechnical considerations, which do not receive enough attention, it should also be pointed out that only little effort has been made in the selection of rotifers. It is surprising that for rotifers, selection has never been considered in commercial aquaculture and that material has been exchanged without any concern on the genetic implications/properties of several clones.

\section{Nutrition}

Cost-effective biomass production of rotifers relies on the use of a cheap food source and explains why baker's yeast was (is) used as an important diet. When applied as a sole diet, it may support the mass production of rotifers in non-axenic culture conditions where micro-organisms provide essential nutrients (Hirayama, 1987). However, it is well known that yeast-fed rotifers lack the essential fatty acids required for the proper 
development and survival of several species of marine fish (see reviews of Watanabe, 1979, 1993; Watanabe et al., 1983; Lubzens et al., 1989).

\subsection{Enrichment with algae}

When good quality algae are available in large numbers, they may be used as an excellent live food diet for boosting the fatty acid content in rotifers. The specific content of the essential fatty acid eicosapentaenoic acid (EPA 20:5n-3) and docosahexaenoic acid (DHA 22:6n-3) in some microalgae (e.g., 20:5n-3 in Nannochloropsis occulata (Watanabe, 1979; Watanabe et al., 1983; Koven et al., 1990; Seto et al., 1992; Sukenik et al., 1993) and 22:6n-3 in Isochrysis galbana and Rhodomonas sp. (Lubzens et al., 1985; Ben-Amotz et al., 1987; Whyte and Nagata, 1990; Sukenik and Wahnon, 1991; Mourente et al., 1993)), and their relatively easy mass culture make them very attractive in commercial hatcheries. Rotifers incubated in these algae cultures (at approximately $5-25 \times 10^{6}$ algae $\mathrm{ml}^{-1}$ ) are incorporating the essential fatty acids in a few hours time and attain a DHA/EPA level above 2 in Isochrysis and below 0.5 for Tetraselmis. However, most of the time, algae of good quality are not available in large enough quantities, are too labour-intensive to be produced or too expensive for rotifer enrichment (Coutteau and Sorgeloos, 1997). For this reason, rotifers are generally boosted in oil emulsions before they are fed to the predators. The latter may be kept in clear water or in "green water". This "green water" consists of $\pm 0.2 \times 10^{6}$ algal cells $\mathrm{ml}^{-1}$ (Tetraselmis, Nannochloropsis, or Isochrysis) and is used as a "water conditioner" and as a nutritional factor to maintain an appropriate HUFA content in the live prey before they are eventually ingested by the predator (Dhert et al., 1998).

The use of storable algal products (algal pastes and frozen algae) has generated some new interest in rotifer cultures (Hamada et al., 1993; Lubzens et al., 1995). Lubzens et al. (1995) accredit this new interest in the new products to the fact that:

1. the algal products can be transported and stored for longer periods (approximately 2 weeks for pastes) relieving the hatcheries from their direct dependence;

2. algae can be cultured under conditions that ensure the highest quality;

3. the chemical composition and quality can be determined in advance;

4. high density rotifer cultures can be obtained (see further).

\subsection{Enrichment with oil emulsions}

For the enrichment or boosting of rotifers, several approaches can be followed: (1) the adjustment of the lipid and vitamin content of the rotifers just before feeding them to other organisms is referred to as short-term enrichment (generally less than $8 \mathrm{~h}$ exposure) and (2) the feeding of rotifers on a complete diet or long-term enrichment (rearing of the rotifers on the enrichment diet for more than $24 \mathrm{~h}$ ).

Many authors have elaborated on both techniques and each of them has its benefits and disadvantages. The short-term enrichment technique has the advantage of being fast and flexible, but very often produces lower quality rotifers with a too high lipid content 
(Dhert et al., 1990; Støttrup and Attramadal, 1992) and poor hygienic quality. The biggest problem in this enrichment technique resides in the fact that a lot of rotifers are lost when they are concentrated (sticking of the rotifers) at high density. Also, transfer of oil to larval rearing tanks with consequent loss of water quality and associated problems of larval viability have been reported (Foscarini, 1988). On top of that, the retention time of the nutrients, which are mainly accumulated in the digestive tract of the rotifers, is very short and can create problems when the rotifers are not eaten immediately.

Since rotifers are not selective for the uptake or catabolism of highly unsaturated fatty acids, high HUFA levels can be accumulated without problem. Especially, DHA, an essential fatty acid that accumulates in the brain of fish during early development where it increases neural functions (Bell et al., 1995), is easily incorporated in rotifers, unlike Artemia which catabolizes this fatty acid (Dhert et al., 1993). Especially for this last reason, the feeding with DHA-enriched rotifers is often prolonged in flatfish cultures where the enrichment at an early stage has been successful in improving pigmentation (Miki et al., 1990; Kanazawa, 1993; Reitan et al., 1994).

In contrast to n-3 PUFA, n-6 PUFAs have been largely neglected in studies on marine fish nutrition. Especially, arachidonic acid (20:4n-6, ARA), the preferred substrate for producing eicosanoids (Tocher and Sargent, 1987; Sargent et al., 1995), can be blended in an optimal ratio with DHA and EPA and retrieved in approximately the same ratio in rotifers without the same risk of preferential catabolism as in Artemia (Estévez et al., 1999). However, the exact balance of DHA, EPA and ARA in the nutrition of larval fish still needs further investigation (Estévez et al., 1999; Sargent et al., in press).

Emulsions with phosholipids have also been used as a more efficient fatty acid (FA) source for fish (McEvoy et al., 1996; Coutteau et al., 1997), but they are immediately broken down in rotifers.

\subsection{Enrichment with vitamins}

The vitamin $\mathrm{C}$ content of rotifers reflects the dietary ascorbic acid (AA) levels both after culture and enrichment. Rotifers cultured on, e.g. instant baker's yeast contain low AA levels (150 $\mathrm{mg} \mathrm{g}^{-1} \mathrm{DW}$ ), while the AA content in Chlorella-fed rotifers may vary (from 1000 to $2300 \mathrm{mg} \mathrm{g}^{-1} \mathrm{DW}$ ) depending on the quality of the algae. In commercial marine fish hatcheries, a wide range of products is used for the culture and subsequent boosting of rotifers with vitamins. Oil-soluble vitamins or derivates from water-soluble vitamins (ascorbyl palmitate (AP) for ascorbic acid) have been formulated in the commercial lipid enrichment products. The non-bioactive ascorbyl palmitate is accumulated by the rotifers together with the oil emulsion and converted to free AA by the enzymes of the rotifers. Merchie et al. (1995) demonstrated that this process was very effective since $5 \%$ AP $(\mathrm{w} / \mathrm{w})$ in the emulsion produced rotifers with an active AA concentration of $1700 \mathrm{mg} \mathrm{g}^{-1} \mathrm{DW}$ after $24 \mathrm{~h}$ enrichment, and this high concentration remained in the rotifers after storage in seawater during the next $24 \mathrm{~h}$. Since the technique has been introduced in Mediterranean bream hatcheries, problems related to stress and operculum deformities have been reduced which might indicate that vitamin $\mathrm{C}$ concentrations in live food may also be critical (Merchie et al., 1997). 


\subsection{Enrichment with proteins}

Only a few reports treat protein content of rotifers and requirements for fish larvae (Watanabe et al., 1983; Øie and Olsen, 1997). The protein content of rotifers is reported to vary between $28 \%$ and $67 \%$ of dry weight, whereas the amino acid profiles of rotifers fed different diets appear to be fairly constant and independent of food quality (Lubzens et al., 1989; Øie and Olsen, 1997). The changes in protein content in rotifers are attributed to their nutritional status; this is for a large part reflected by the applied feeding strategy and the general rotifer condition, more specifically the reproduction rate of the rotifer. The range of variation is large enough to affect larval rearing success especially during first feeding of marine fish larvae. Øie and Olsen (1997) improved the modified protein/lipid ratio after short-term enrichment of rotifers with lipid-rich diets which significantly increased the lipid content, whereas the protein content remained constant resulting in a low protein/lipid ratio. Also, during the rearing of rotifers, the protein/lipid content is subject to variation and is positively correlated with the specific growth rate of the rotifers. Since rotifers are generally cultured in batch systems in which the specific growth rate tends to decrease significantly towards the end of the culture period, this means that the protein/lipid balance in rotifers may show variations as high as 150-200\% depending if the rotifers are harvested shortly after restocking or towards the end of the culture period. Especially in first feeding marine fish larvae, it is important to provide high nutritional quality rotifers since the nutritional content of the rotifers tends to decrease after transfer to the fish tanks in clear water systems (Øie et al., 1995; Olsen et al., 1993; Reitan et al., 1993). For turbot, for instance, a positive effect was seen on growth and survival when fast-reproducing rotifers (i.e. high protein content with high protein/lipid ratio) were fed (Øie et al., 1997).

\subsection{Use of formulated diets}

The long-term enrichment is based on the continuous administration of the essential nutritional compounds during the rearing of the rotifers. This ensures that not only the digestive tract of the animals but also their complete body has been modified to a composition close to that of the diet on which the rotifers were grown. Rotifers fed following this feeding/enrichment strategy are nutritionally more stable and loose their reserves very slowly. This feeding strategy is more popular in continuous cultures or recirculation systems. The Japanese model is making use of condensed Chlorella paste supplemented with vitamins and HUFA (Fu et al., 1997; Yoshimura et al., 1997a), while the European model is working with a completely formulated diet.

Culture Selco ${ }^{\circledR}$ (CS) is the most widely used diet for rotifers. It has an excellent HUFA composition, respectively, 5.4, 4.4 and $15.6 \mathrm{mg} \mathrm{g}^{-1}$ dry matter of EPA, DHA and (n-3) HUFA. This HUFA composition results in significantly higher DHA and EPA concentrations in rotifers than for cultures grown on mixtures of algae and baker's yeast (Léger et al., 1989). The level of total lipids is approximately $18 \%$ and thus less fat than the oil emulsions. Since the use of CS allows direct enrichment of the rotifers without the need of a cumbersome bioencapsulation treatment, complementary diets as Protein Selco ${ }^{\circledR}$ (PS) and DHA Culture Selco ${ }^{\circledR}$ (DHA-CS) have been launched in order to 
incorporate higher levels of protein and DHA. The advantage of direct (or long-term) enrichment are multiple: the fatty acid profile obtained is stable and reproducible, the lipid content is comparable to that obtained in wild zooplankton, rotifer losses are lower and labour costs can be reduced. Also, for the high density culture of rotifers, new diet formulations are being proposed (Suantika et al., 2000b; De Wolf et al., 1998).

\section{Culture conditions}

In 1964, the Japanese Sea-Farming Fisheries Association (JSFFA, Yashima Station) initiated the mass culture of marine Chlorella and rotifers using a "daily tank-transfer" method (Hirata, 1980). These rotifers were used as a commercial diet for red sea bream (Fukusho, 1989). Since these early pioneering days, the demand for rotifers has continuously increased and several culture techniques have been developed for rotifer mass production (Fukusho, 1983, 1989). Until the late eighties, the most popular techniques in laboratory and commercial hatcheries were classified as batch cultures (Walz et al., 1997) and semi-continuous cultures (Snell, 1991). More sophisticated methods have been developed, such as continuous systems with several degrees of mechanization and automation (Morizane, 1991; Fu et al., 1997; Abu-Rezq et al., 1997), and the ultra-high density mass culture of rotifers on algae (Yoshimura et al., 1996) and on artificial diets (Suantika et al., 2000a).

\subsection{Batch cultures}

Batch cultivation, due to its simplicity, is probably the most common type of rotifer production in marine fish hatcheries (Fukusho, 1983; Nagata and Hirata, 1986; Snell, 1991). The culture strategy consists in either the maintenance of a constant culture volume with an increasing rotifer density or the maintenance of a constant rotifer density by increasing the culture volume. In the batch culture, a total harvest of the rotifers is applied with part of the rotifers used as food for fish larvae and part used as inoculum for the next culture (Hirata, 1980; Lubzens, 1987). Using an artificial diet (e.g. Culture Selco $\left.{ }^{\circledR}\right)$, the density at harvest time is about 600 rotifers $\mathrm{ml}^{-1}$ after 4 days culture starting from 200 to 250 rotifers $\mathrm{ml}^{-1}$ (Dhert, 1996; Suantika et al., 2000a). Generally, the size of the tanks for batch culture is flexible, 500- to 1000-1 plastic tanks and up to 10-ton concrete tanks are used. Many disadvantages are, however, attributed to the batch culture system: the cultures are subjected to highly variable conditions both in growth performance in terms of biochemical composition of the rotifer population, unstable physico-chemical water parameters, low efficiency in terms of labour and utilization of infrastructure. These problems contribute to unstable/unpredictable culture conditions and a relatively low production yield (Walz et al., 1997) at high cost. A lot of improvements have been made to create more stable culture and rotifer production in batch cultures. Boraas and Benneth (1988) and Walz et al. (1997) have developed a turbidostat system. In this system, the rotifer production is stabilized by maintaining constant algal densities by turbidity regulation. Increased interest is also seen in the use 
of artificial diets (see Section 2). These diets are becoming more successful and allow reliable production cycles (Candreva et al., 1996; De Wolf et al., 1998).

\subsection{Semi-continuous cultures}

The semi-continuous culture is also known as "thinning culture" since the rotifer density is kept constant by periodic harvesting (Coves et al., 1990; Girin and Devauchele, 1974). Contrary to the batch culture, this long-term culture is maintained at low densities for a period of 7-14 days without water renewal (Lubzens, 1987). The size of the culture tank is usually larger than that used in the batch cultures. The inoculated density varies between 50 and 200 individuals $\mathrm{ml}^{-1}$. This rotifer density might reach 300 to over 1000 individuals $\mathrm{ml}^{-1}$ in 3-7 days, using microalgae and/or baker's yeast as food.

\subsection{High density cultures}

Japanese scientists have developed intensive ultra-high density rotifer culture techniques. The latest ultra-high density rotifer mass culture (maximum density from 20,000 to 35,000 rotifers $\mathrm{ml}^{-1}$ ) has been developed based on concentrated freshwater Chlorella as food (Yoshimura et al., in press, 1995, 1997a; Fu et al., 1997). Although this technique enables higher productions of rotifers compared to the batch culture system, the high food supply necessary to support the cultures causes accumulation of organic wastes in the culture water (Yoshimura et al., 1997b,c). Especially, the high ammonium concentrations and resulting free ammonia toxicity are reduced by lowering the $\mathrm{pH}$ of the culture water by regular monitoring (Yoshimura et al., 1995). The excessive foam formation is controlled by the use of antifoam, but this is toxic for rotifers (Yoshimura et al., 1996). Also, the viscosity of the culture water tends to increase during the rearing process resulting in a lower oxygen exchange and reduced rotifer feeding (Hagiwara, personal communication).

In order to solve the problem of water quality and to improve culture stability, as well as to reduce labour and utilized tank capacity, new methods have been developed for the high-density rearing of rotifers in continuous culture. In a chemostat culture system for rotifer production, Abu-Rezq et al. (1997) achieved a daily rotifer production of $2 \times 10^{9}$ individuals in a $1-\mathrm{m}^{3}$ tank. In this system, the $\mathrm{pH}$ level could be stabilized at $\mathrm{pH} 7.5-8.1$ while the dissolved oxygen remained high (6.8-5.6 ppm) during a 3-month culture period. $\mathrm{Fu}$ et al. (1997) developed an automatic continuous culture system with a filtration unit, a culture unit and a harvest unit to improve the stability in the mass production of rotifers. In this system, filtered water and food (Chlorella vulgaris) are continuously supplied to a rotifer tank and the same amount of culture water is transferred into a harvesting tank where, on a daily basis, a rotifer biomass of $2.1 \times 10^{9}$ S-type rotifers or $1.7 \times 10^{8}$ L-type rotifers can be harvested per meter cube. Another high density mass culture system for rotifers was developed by Yoshimura et al. (1997a). In this system, filtering equipment was used to prevent particulate organic matter, debris and bacteria from clogging the collection net during harvest. The last progress in the area of high density rotifer production has been achieved in a closed 
recirculation system. A protein skimmer equipped with an ozone generator is removing most of the suspended matter and part of the soluble components before the water is treated in a submerged biofilter. This biofilter has been seeded with a single inoculum of nitrifying bacteria at the start of the culture. The combination of improved diet formulation and the new culture design enables rotifer densities of 23,000 individuals $\mathrm{ml}^{-1}$ (Dhert et al., in press). The rotifer production unit has been tested on a commercial scale in $1-\mathrm{m}^{3}$ tanks yielding $3.4 \times 10^{10}$ rotifers in 21 days with a daily rotifer harvest of $2.1 \times 10^{9}$ rotifers (approximately $30 \%$ of the standing crop). Using this system, low ammonium $\left(0-0.8 \mathrm{mg} \mathrm{l}^{-1}\right)$ and nitrite $\left(0.2-3.5 \mathrm{mg}^{-1}\right)$ concentrations can be maintained during the entire culture period. Thanks to the natural carbonate pebbles in the biofilter, the $\mathrm{pH}$ is kept at 7.3 without adjustments during the culture period. The microbial counts also remained stable during the whole culture period and were about 10-100 times lower than in batch systems.

The advantages of this rearing procedure reside in a considerable reduction in the maintenance of the culture, high productivity and the production of cleaner rotifers with the possibility for further automation of the system.

\section{Microbial conditions}

Bacteria are always associated with mass production of rotifers and may cause unexpected mortality or suppressed growth to rotifers. In some other cases, no harm is caused to the rotifers but infected rotifers cause a detrimental effect on fish larvae, resulting in poor survival and growth (Perez-Benavente and Gatesoupe, 1988b; Gatesoupe, 1989). Although most bacteria are not pathogenic for rotifers, their proliferation must be avoided since a real risk of accumulation and transfer via the food chain can cause detrimental effects on the predator (Dhert, 1996).

\subsection{Rotifers as vector of bacteria}

It is assumed that rotifers, the first food administered to fish larvae, are the major carriers of bacteria (Muroga and Yasunobu, 1987; Munro et al., 1993a, 1994). Although in most hatcheries, special efforts are made to keep the rotifer cultures as clean as possible (Minkoff, 1994; Tanasomwang and Muroga, 1989), the billions of rotifers and their accompanying food inevitably create a high load of organic material which is rapidly colonised by bacteria. These rearing conditions allow the bacteria to grow fast (Skjermo et al., 1997; Skjermo and Vadstein, 1999; Verschuere et al., 1997) and can also change the normal interaction between bacteria and rotifers to one that is detrimental (Vadstein et al., 1993).

Gatesoupe (1991a) showed that an antibiotic treatment of rotifers prior to the administration to the larvae resulted in an increased survival of the larvae. It is obvious that one should consider new measures to reduce bacterial loads as well as to selectively manipulate the microflora both in the live feeds produced in the hatchery and in the culture water prior to stocking of the fish larvae. Applications of disinfection procedures such as the ones successfully used in Artemia hatching and enrichment (Dehasque et al., 
1993; Gomezgil-RS et al., 1994; Provasoli and Shiraishi 1959) are lethal for rotifers. In this respect, several attempts have been made to reduce bacterial numbers in rotifers by the use of disinfectants (Dermaux, 1996; Miyakawa and Muroga, 1988; Munro et al., 1993a) or by physical treatments (Munro et al., 1999; Verdonck et al., 1991; Rodriguez et al., 1991; Allen Davis and Arnold, 1997). Most of these treatments are either not effective since they only reduce the bacterial number without avoiding the risk for transfer to the predator or can even create additional problems (e.g. formation of by-products or toxic compounds).

In some cases, the treatment of rotifers with antibacterial agents has resulted in a suppressed growth of Vibrionaceae which are suspected of causing extremely heavy mortalities to turbot larvae and early juveniles (Minkoff, 1994; Tanasomwang and Muroga, 1989). Other specific treatments such as rinsing (Verdonck et al., 1991), fresh-water bath-treatment (Rodriguez et al., 1991) and antibiotic-mixtures (Gatesoupe, 1987; Perez-Benavente and Gatesoupe, 1988a,b; Tanasomwang and Muroga, 1989) have been reported but are not disinfecting properly.

The use of antibiotics seemed an easy solution to solve these problems, but their profilactic use caused several secondary effects (interaction with the available gut microflora of larvae and increase in the frequency of strains to resistance) and adverse environmental impacts (Minkoff and Broadhurst, 1994; Smith, 1991; Kinkelin and Michel, 1992). Since this approach was clearly not the most appropriate, the bacterial dynamics in rotifer populations were studied.

Although nutritional and bacterial conditions might suppress growth (Hirayama, 1987; Munro et al., 1999; Nicolas et al., 1989), it is generally accepted that most bacteria are not pathogenic for rotifers but that their proliferation should be avoided since a real risk of accumulation and transfer via the food chain can cause detrimental effects on the predator (Dhert, 1996).

\subsection{Effect of associated microbiota on rotifer cultures}

Although little is known about the importance of the microbial biomass in live feed production systems, the microbiota associated with it seems to play a major role in the instability and variability of the live feed cultures themselves (Gatesoupe, 1991a,b; Gatesoupe et al. 1989; Harzevili et al., 1997; Hirayama, 1987; Skjermo and Vadstein, 1993; Yu et al., 1989, 1990) and of the cultures of the marine predator-larvae (Muroga et al., 1987; Nicolas et al., 1989; Perez-Benavente and Gatesoupe, 1988a,b; Tanasomwang and Muroga, 1990; Verdonck et al., 1997). Consequently, there is currently interest in manipulating the composition of the microbial community towards a potentially more reliable and beneficial composition.

A review on the bacterial counts found on live food organisms was published by Minkoff and Broadhurst (1994). Usually, the aerobic bacteria population ranges from $10^{7}$ to $10^{10} \mathrm{CFU} / \mathrm{g}$ in live diets and $10^{4}$ to $10^{7} \mathrm{CFU} / \mathrm{ml}$ in culture water (Miyakawa and Muroga, 1988; Tanasomwang and Muroga, 1990; Nicolas et al., 1989; Skjermo and Vadstein, 1993).

Overall, it is stated that rotifers can concentrate up to $10^{5} \mathrm{CFU} /$ individual in their gut, while in the culture water, the bacterial concentration remain around $10^{7} \mathrm{CFU} / \mathrm{ml}$ 
(Nicolas et al., 1989; Skjermo and Vadstein, 1993; Coves et al., 1990). Nicolas et al. (1989) also observed that the ratio between direct counting and plate counting was very small, indicating that most bacteria were probably active and able to multiply. By means of electron scanning microscopy (SEM), Munro et al. (1993b) stated that the majority of bacterial strains associated with rotifers were located on the external surface. Depending on the feed quality, rotifers may graze more on bacteria. Hino et al. (1997) and Nicolas et al. (1989) gave experimental evidence that rotifers, fed with a low quality feed, grazed more bacteria in order to find the nutrients lacking. In this way, bacteria could compensate for the deficit as also observed by Yasuda and Taga (1980). Hence, the bacterial accumulation in the gut of rotifers results from grazing rather than from internal multiplication (Vadstein et al., 1993).

As it is already explained, most of the hatcheries still rely on batch cultures to obtain the live feed for their larvae. In terms of microbiology, these systems are very unpredictable since normally, no microbial control is performed after the disinfection of the rearing water at the start of the rotifer culture. The development of the microbiota in such an open ecosystem is believed to occur in two steps, based on the r/K-concept (Pianka, 1970; Salvesen et al., 1999). During the first step, the r-strategists, i.e. fast-growing and often regarded as opportunistic bacteria, will develop, whereafter K-selection will occur as the community starts to reach a mature stage. As rotifer cultures often do not reach the mature stage, as it takes only 4-7 days to complete one cycle, together with the fact that the microbiota is continuously disturbed due to the addition of feed and the continuous growth of the rotifers, the selection for K-strategist is supposed not to happen. Therefore, it is important to select bacteria that can easily survive under the same conditions as the rotifers, i.e. so-called r-strategists and those which have a positive effect on the rotifers.

In the new culture techniques based on long-term cultures (1 month) and often associated with a recirculation system, the development of a mature microbiota and the presence of $\mathrm{K}$-strategist is believed to be important. How these communities develop is still a question, but it is believed to happen.

Bacteria present in the culture tanks may either be harmful to the rotifers (Hagiwara et al., 1995; Maeda and Hino, 1991; Yu et al., 1990) or serve as food and contribute to their growth and reproduction (Ushiro et al., 1980; Hagiwara et al., 1994; Rombaut et al., 1999). Vibrio anguillarum was reported as a pathogen causing crashes in rotifer cultures (Shiri Harzevilli et al., 1995, 1997). Balompapueng et al. (1997a) found that bacterial strains such as Plavobacterium, Aeromonas and Vibrio sp. isolated from the unstable collapsing rotifer cultures showed toxicity for the rotifer population. Comps and Menu (1997) reported that infectious diseases (viral and fungal) might also be associated with reduced productivity of rotifer mass cultures and abnormal mortality. Under good culture conditions, bacteria have been found to form flocks or attach to detritus to reach a size large enough to be eaten by the rotifer (Hino, 1993). The bacteria can thus supply substances which are deficient in certain diets, especially simple ones (yeast) (Coves et al., 1990). They are known to synthesize B-group vitamins, particularly $B_{12}$, which are necessary for Brachionus to reproduce.

The presence and proliferation of bacteria is inherent to the continuous maintenance of live stock cultures of Brachionus and is enforced by the inoculation of new cultures 
from old cultures (Dhert and Sorgeloos, 1995). As the effectiveness of the present disinfection procedures is not sufficient to guarantee complete sterile conditions, and as the awareness of the people towards the routine use of antibiotics is increasing, there is a need for a new (bio)technology to control the microbiota associated with the rotifers. Some authors already mentioned the use of single or mixed cultures of selected bacteria to modify or manipulate the microbial community in water and sediment, to reduce or eliminate pathogenic species of micro-organisms and to improve growth and survival of the targeted species. The success of this method depends on the microbiota present in the system at the moment of inoculation. Therefore, the start-conditions are of big importance and axenic start-cultures may improve the subsequent cultures.

Since disinfection procedures cannot be performed during the amictic reproduction cycle of the rotifers, Lubzens (1981) proposed to use rotifer-resting eggs (the product of mictic reproduction) as starter cultures. Resting eggs are very resistant to disinfection procedures and can easily be treated without loosing their hatching ability (Balompapueng et al., 1997b; Dhert et al., 1997; Hagiwara et al., 1994). Hence, the use of this off-the-shelf product could solve the burden of maintaining stock cultures and reduce the risk of contamination with ciliates or pathogenic bacteria (Dhert and Sorgeloos, 1995).

A recent study by Lee et al. (1997) revealed that a certain bacteria strain can be used as food for B. plicatilis to enhance the growth rate. The application of this approach (Hagiwara et al., 1994; Hino et al., 1997; Lee et al., 1997; Rombaut et al., 1999; Yasuda and Taga, 1980; Yu et al., 1989) seems to be promising to control the microbiota and to reduce the variability in the production of rotifers.

The application of selected bacteria may stimulate the growth of rotifers (Bogaert et al., 1993; Gatesoupe et al., 1989; Gatesoupe, 1991a; Rombaut et al., 1999; Hirata et al., 1998) or inhibit the development of pathogens as Aeromonas salmonicida (Gatesoupe, 1991a) or V. anguillarum (Harzevili et al., 1997). The mode of action of these probionts remains unclear and several hypotheses have been suggested:

1. nutrition (source of limiting nutrients, extracellular enzymes, transformation of the diet composition, transformation of soluble to particulate material which can be ingested);

2. competition among bacteria for essential nutrients;

3. competition among bacteria for adhesion (pre-emptive colonisation);

4. antagonism for pathogens;

5. immunostimulants;

6. improvement of the water quality interaction with phytoplankton;

7. reduction of blue-green algae.

The effect of bacterial isolates to axenic rotifer cultures on the asexual reproduction has been investigated by Hagiwara et al. (1994) and Rombaut et al. (1999). Both research groups were able to select some bacterial strains that were able to stimulate asexual reproduction. Although Hagiwara et al. (1994) did not find any strain that could significantly improve the specific growth rate of rotifer cultures, Rombaut et al. (1999) found significant differences in the average growth rate of the cultures inoculated with 
different bacterial isolates. The effect of the probionts could already be detected as early as $48 \mathrm{~h}$ after the addition of the bacterial cultures. It resulted in an increase in the egg ratio of at least $50 \%$ for the best isolates and a doubling of the specific growth rate. When these experiments were repeated in xenic condition, the beneficial effect of the probionts was lower but still enabled a $50 \%$ increase in the population growth compared to the control treatment.

\section{Conclusion}

The variability in the success of larval rearing of marine fish can definitely be attributed to uncontrolled changes in the quality of live food. The first cause of variation can be explained by the difference in physiological and nutritional stages of reproducing rotifers. This variation is intrinsic to the population dynamics and cannot be completely excluded. Efforts, however, can be made to replace the existing batch culture techniques by more stable rearing techniques, where more attention is paid to the environmental conditions and water quality. It is believed that under these improved rearing conditions and with the use of less-polluting, high quality diets, combined with an appropriate bacterial management, tremendous improvements towards sustainable rotifer quality and production can be achieved.

\section{Acknowledgements}

The studies of the authors have been supported by research contracts from FWO (project G. 006396 N), IWT, the Indonesian Government (Department Biology-Institut Teknologi Bandung, contract no. 010/CG/III/URGE/1997, IBRD Loan no. 3754IND) and INVE Aquaculture NV, Belgium.

\section{References}

Abu-Rezq, T., Al-Shimmari, J., Dias, P., 1997. Live food production using batch culture and chemostat system in Kuwait. Hydrobiologia 358, 173-178.

Allen Davis, D., Arnold, C.R., 1997. Tolerance of the rotifer Brachionus plicatilis to ozone and total oxidative residuals. Ozone: Sci. Eng. 19, 457-469.

Balompapueng, M.D., Hagiwara, A., Nishi, A., Imaizumi, K., Hirayama, K., 1997a. Resting egg formation of the rotifer Brachionus plicatilis using a semi-continuous culture method. Fish. Sci. 63, 236-241.

Balompapueng, M.D., Munuswamy, N., Hagiwara, A., Hirayama, K., 1997b. Effect of disinfectants on the hatching of marine rotifer resting eggs of Brachionus plicatilis Muller. Aquacult. Res. 28 (7), $559-565$.

Bell, M.V., Batty, R., Navarro, J.C., Sargent, J.R., Dick, J.R., 1995. Dietary deficiency of docosahexaenoic acid impairs vision at low light intensities in juvenile herring (Clupea harengus L.). Lipids 30, 443-449.

Ben-Amotz, A., Fishler, R., Schneller, A., 1987. Chemical composition of dietary species of marine unicellular algae and rotifers with emphasis on fatty acids. Mar. Biol. 95, 31-36.

Bogaert, P., Dehasque, M., Sorgeloos, P., 1993. Probiotic effects of bacteria on the growth of the rotifer Brachionus plicatilis in culture. Presented at the World Aquaculture Conference, Torremolinos, Spain. Eur. Aqua. Soc., Special Publication no. 19, Oostende, Belgium, pp. 1-7. 
Boraas, M.E., Bennet, W.N., 1988. Steady-state rotifer growth in a two-stage, computer-controlled turbistat. J. Plankton Res. 10, 1023-1038.

Candreva, P., Dhert, P., Novelli, A., Brissi, D., 1996. Potential gains through alimentation nutrition improvements in the hatchery. In: Chatain, B., Sargalia, M., Sweetman, J., Lavens, P. (Eds.), Seabass and Seabream Culture: Problems and Prospects. An International Workshop, 16-18 October 1996, Verona, Italy. Eur. Aqua. Soc., 388, pp. 149-159, Oostende, Belgium.

Comps, M., Menu, B., 1997. Infectious diseases affecting mass production of the marine rotifer Brachionus plicatilis. In: Hagiwara, A., Snell, T.W., Lubzens, E., Tamaru, C.S. (Eds.), Live Food in Aquaculture. Hydrobiologia, vol. 358, pp. 179-183.

Coutteau, P., Sorgeloos, P., 1997. Manipulation of dietary lipids, fatty acids, and vitamins in zooplankton cultures. Freshwater Biol. 38, 501-512.

Coutteau, P., Geurden, I., Camara, M.R., Bergot, P., Sorgeloos, P., 1997. Review on the dietary effects of phospholipids in fish and crustacean larviculture. Aquaculture 155, 149-164.

Coves, D., Audineau, P., Nicolas, J.L., 1990. Rotifer-rearing technology. In: Barnabe, G. (Ed.), Aquaculture, vol. I, Ellis Harwood, West Sussex, England, pp. 232-245.

Dehasque, M., Devresse, B., Sorgeloos, P., 1993. Effective suppression of bacterial bloom during hatching and enrichment of Artemia and its applicability in fish/shrimp hatcheries. From Discovery to Commercialization-Book of Abstracts. Torremolinos, Spain. Eur. Aqua. Soc., Special Publication 19, p. 347, Oostende, Belgium.

Dehasque, M., De Wolf, T., Candreva, P., Coutteau, P., Sorgeloos, P., 1998. Control of bacterial input through the live food in marine fish hatcheries. In: Grizel, H., Kestemont, P. (Eds.), Aquaculture and Water: Fish Culture, Shellfish Culture and Water Usage. Abstracts of Contributions Presented at the International Conference Aquaculture Europe '98, Bordeaux, France, October 7-10. Eur. Aqua. Soc., Oostende, pp. $66-67$.

Dermaux, V., 1996. Reduktie van de bakteriële kontaminatie bij de productie van rotiferen, Thesis, Gent, 128 $\mathrm{pp}$.

De Wolf, T., Candreva, P., Dehasque, M., Coutteau, P., 1998. Intensification of rotifer batch culture using an artificial diet. Eur. Aqua. Soc., Spec. Publ. 26, 68-69.

Dhert, P., 1996. Rotifers. In: Sorgeloos, P., Lavens, P. (Eds.), Manual on the production and use of live food for aquacultre. Fisheries technical paper no. 361. Food and Agriculture Organization of the United Nations, Rome, pp. 49-78.

Dhert, P., Sorgeloos, P., 1995. Live feeds in aquaculture. In: Nambier, K.P.P., Singh, T. (Eds.), Aquaculture Towards the 21st Century. INFOFISH-AQUATECH Conference, Colombo, Sri Lanka, 29-31 August 1994. INFOFISH, Kuala Lumpur, Malaysia, p. 287.

Dhert, P., Lavens, P., Duray, M., Sorgeloos, P., 1990. Improved larval survival at metamorphosis of Asian seabass (Lates calcarifer) using-3 HUFA-enriched live food. Aquaculture 128, 315-333.

Dhert, P., Sorgeloos, P., Devresse, B., 1993. Contributions towards a specific DHA enrichment in the live food Brachionus plicatilis and Artemia sp. In: Reinertsen, H., Dahle, L.A., Jorgensen, L., Tvinnereim, K. (Eds.), Fish Farming Technology. Balkema, Rotterdam, Netherlands, pp. 109-115.

Dhert, P., Schoeters, K., Vermeulen, P., Sun, J., Gao, S., Shang, Z., Naihong, X., Van Duffel, H., Sorgeloos, P., 1997. Production, disinfection and evaluation for aquaculture applications of rotifer resting eggs from Bohai Bay, P.R. of China. Aquacult. Int. 5, 105-112.

Dhert, P., Divanach, P., Kentouri, M., Sorgeloos, P., 1998. Rearing techniques for difficult marine fish larvae. World Aquacult. 48-55, March.

Dhert, P., Suantika, G., De Wolf, T., Okechi, J.K., Bonaldo, A., Sorgeloos, P., 2000. The use of ozone in a high rotifer recirculation system. In: Flos, R., Creswell, L. (Eds.), Responsible Aquaculture in the New Millenium. AQUA 2000, Nice, France, May 2-6, 2000. Eur. Aqua. Soc., Special Publication 28, p. 182.

Estévez, A., McEvoy, L.A., Bell, J.G., Sargent, J.R., 1999. Growth, survival, lipid composition and pigmentation of turbot (Scophthalmus maximus) larvae fed live-prey enriched in Arachidonic and Eicosapentaenoic acids. Aquaculture 180, 321-343.

Foscarini, R., 1988. Intensive farming procedure for red sea bream (Pagrus major) in Japan. Aquaculture 72, 191-246.

Fu, Y., Hada, H., Yamashita, T., Yoshida, Y., Hino, A., 1997. Development of continuous culture system for stable mass production of the marine rotifer Brachionus. Hydrobiologia 358, 145-151. 
Fukusho, K., 1983. Present status and problems in culture of the rotifer Brachionus plicatilis for fry production of marine fishes in Japan. Symposium International De Aquacultura, Coquimbo, Chile, Sept., pp. 361-374.

Fukusho, K., 1989. Biology and mass production of the rotifer, Brachionus plicatilis I. Int. J. Aqua. Fish Technol. 1, 292-299.

Gatesoupe, F.J., 1987. Further advances in the nutritional and antibacterial treatments of rotifers as food for turbot larvae, Scophthalmus maximus L. Aquaculture Europe '87 International Conference. INRA/ IFREMER, Brest, France, pp. 1-20.

Gatesoupe, F.J., 1989. Further advances in the nutritional and antibacterial treatments of rotifers as food for turbot larvae, Scophthalmus maximus L. In: De Pauw, N., Ackerfots, H., Wilkins, N. (Eds.), Aquaculture -A Biotechnology in Progress. Eur. Aqua. Soc., vol. 2, Bredene, Belgium, pp. 721-730.

Gatesoupe, F.J., 1991a. The effect of three strains of lactic bacteria on the production rate of rotifers, Brachionus plicatilis, and their dietary value for larval turbot, Scophthalmus maximus. Aquaculture 96, 335-342.

Gatesoupe, F.J., 1991b. The use of probiotics in fish hatcheries: results and prospects. ICES 1991, Mariculture Committee Paper 37.

Gatesoupe, F.J., Arakawa, T., Watanabe, T., 1989. The effect of bacterial additives on the production rate and dietary value of rotifers as food for Japanese flounder, Paralichthys olivaceus. Aquaculture 83, 39-44.

Girin, M., Devauchele, B., 1974. Production du rotifere Brachionus plicatilis. O.F. Muller en elevage mixte avec le copepode tisbe farcata (Baird). 3rd Meeting I.C.E.C., Work Group Maricult. Act. Coll. CNEXO 1, pp. 87-99.

Gomezgil-RS, B., Abreu-Grobois, F.A., Romero-Jarero, J., De Los Herrera-Vega, M., 1994. Chemical disinfection of Artemia nauplii. J. World Aquacult. Soc. 25, 579-583.

Hagiwara, A., Hamada, K., Hori, S., Hirayama, K., 1994. Increased sexual reproduction in Brachionus plicatilis (Rotifera) with the addition of bacteria and rotifer extracts. J. Exp. Mar. Biol. Ecol. 181, 1-8.

Hagiwara, A., Jung, M.M., Sato, T., Hirayama, K., 1995. Interspecific relations between the marine rotifer Brachionus plicatilis and zooplankton species contaminating in the rotifer mass culture tank. Fish. Sci. 61, 623-627.

Hamada, K., Hagiwara, A., Hirayama, K., 1993. Use of preserved diet for rotifer Brachionus plicatilis resting egg formation. Nippon Suisan Gakkaishi 59, 85-91.

Harzevili, A.R.S., Van Duffel, H., Defoort, T., Dhert, P., Sorgeloos, P., Swings, J., 1997. The influence of a selected bacterial strain Vibrio anguillarum TR 27 on the growth rate of rotifers in different culture conditions. Aquacult. Int. 5, 183-188.

Hino, A., 1993. Present culture systems of the rotifer (Brachionus plicatilis) and the function of microorganisms. In: Lee, C.S., Su, M.S., Liao, I.C. (Eds.), Finfish Hatchery in Asia: Proceedings of finfish hatchery in Asia'91. TLM Conference Proceedings 3, 61-710 Tungkang Marine Laboratory, Taiwan Fisheries Research Institute, Tungkang, Pingung, Taiwan, p. 14.

Hino, A., Aoki, S., Ushiro, M., 1997. Nitrogen-flow in the rotifer Brachionus rotundiformis and its significance in mass cultures. Hydrobiologia $358,77-82$.

Hirata, H., 1980. Culture methods of the marine rotifer, Brachionus plicatilis. Min. Rev. Data file Fish. Res. Kagoshima Univ. 1, 27-46.

Hirata, H., Murata, O., Yamada, S., Ishitani, H., Wachi, M., 1998. Probiotic culture of the rotifer Brachionus plicatilis. Hydrobiologia 387, 495-498.

Hirayama, K., 1987. A consideration of why mass culture of the rotifer Brachionus plicatilis with baker's yeast is unstable. Hydrobiologia 147, 269-270.

Kanazawa, A., 1993. Nutritional mechanisms involved in the occurrence of abnormal pigmentation in hatchery-reared flatfish. J. World Aquacult. Soc. 24, 162-166.

Kinkelin, P.D., Michel, C., 1992. The use of drugs in aquaculture. INFOFISH International 4/92, pp. 45-49.

Koven, W.M., Tandler, A., Kissil, G.W., Sklan, D., Friezlander, O., Harel, M., 1990. The effect of dietary (n-3) polyunsaturated fatty acids on growth, survival and swimbladder development in Sparus aurata larvae. Aquaculture 91, 131-141.

Lee, W.J., Park, Y.S., Park, Y.T., Kim, S.J., Kim, K.Y., 1997. Studies on the availability of marine bacteria and the environmental factors for the mass culture of the high quality of Rotifera and Artemia: 1. Change 
of fatty acid and amino acid composition during cultivation and rotifer, Brachionus plicatilis by marine bacteria Erythrobacter sp. S pi-I. J. Korean Fish. Soc. 30, 319-328.

Léger, P., Grymonpre, D., Van Ballaer, E., Sorgeloos, P., 1989. Advances in the enrichment of rotifers and Artemia as food sources in marine larviculture. Aquaculture Europe'89, Short communications and Abstracts, Eur. Aqua. Soc., Bordeaux, France, Special Publication, vol. 10, pp. 141-142.

Lubzens, E., 1981. Rotifer resting eggs and their application to marine aquaculture. Spec. Publ. - Eur. Maric. Soc. 6, 163-179.

Lubzens, E., 1987. Raising rotifers for use in aquaculture. Hydrobiologia 147, 245-255.

Lubzens, E., Marko, A., Tietz, A., 1985. De novo synthesis of fatty acids in the rotifer Brachionus plicatilis. Aquaculture 47, 27-37.

Lubzens, E., Tandler, A., Minkoff, G., 1989. Rotifers as food in aquaculture. Hydrobiologia 186-187, $387-400$.

Lubzens, E., Gibson, O., Zmora, O., Sukenik, A., 1995. Potential advantages of frozen algae (Nannochloropsis sp.) for rotifer (Brachionus plicatilis) culture. Aquaculture 133, 295-309.

Maeda, M., Hino, A., 1991. Environmental management for mass culture of rotifer, Brachionus plicatilis. Rotifer and Microalgae Culture Systems. Proc. US-Asia Workshop. The Oceanic Institute, Honolulu, pp. $125-133$.

McEvoy, L.A., Navarro, J.C., Hontario, F., Amat, F., Sargent, J.R., 1996. Two novel Artemia enrichment diets containing polar lipid. Aquaculture 144, 339-352.

Merchie, G., Lavens, P., Dhert, P., Dehasque, M., Nelis, H., De Leenheer, A., Sorgeloos, P., 1995. Variation of ascorbic acid content in different live food organisms. Aquaculture 134, 325-337.

Merchie, G., Lavens, P., Sorgeloos, P., 1997. Optimization of dietary vitamin C in fish and crustacean larvae: a review. Aquaculture 155, 165-181.

Miki, N., Taniguchi, T., Hamakawa, H., Yamada, Y., Sakurai, N., 1990. Reduction of albinism in hatchery-reared flounder "hirame", Paralichthys olivaceus by feeding on rotifer enriched with vitamin A. Suisan Zoshosku 38, 147-155.

Minkoff, G., 1994. Control of Vibrio type bacteria in rotifer mass cultures. Tinamenor S.A., pp. 1-8.

Minkoff, G., Broadhurst, A.P., 1994. Intensive production of turbot Scophthalmus maximus fry. In: Lavens, P., Remmerswaal, R.A.M. (Eds.), Turbot Culture: Problems and Prospects, Gent, Belgium. Eur. Aqua. Soc., Special Publication, vol. 22, pp. 14-31.

Miyakawa, M., Muroga, K., 1988. Bacterial flora of cultured rotifer Brachionus plicatilis (English abstract). Suisan Zoshoku 35, 237-243.

Morizane, T., 1991. A review of automation and mechanization used in the production of rotifer in Japan. Rotifer and Microalgae Culture Systems. Proceeding of US-Asia Workshop. The Oceanic Institute, Honolulu, Hawaii, pp. 79-88.

Mourente, G., Rodriguez, A., Tocher, D.R., Sargent, J.R., 1993. Effects of dietary docosahexaenoic acid (DHA;22:6n-3) on lipid and fatty acid compositions and growth in gilthead sea bream (Sparus aurata L.) larvae during first feeding. Aquaculture 112, 79-98.

Munro, P.D., Birkbeck, T.H., Barbour, A., 1993a. Bacterial flora of rotifers (Brachionus plicatilis): evidence for a major location on the external surface and methods for reducing the rotifer bacterial load. In: Reinertsen, H., Dahle, L.A., Jorgensen, L., Tvinnereim, K. (Eds.), Fish Farming Technology. A.A. Balkema, Rotterdam, pp. 93-100.

Munro, P.D., Birkbeck, T.H., Barbour, A., 1993b. Influence of rate of bacterial colonization of the gut of turbot larvae on larval survival. In: Reinertsen, H., Dahle, L.A., Jorgensen, L., Tvinnereim, K. (Eds.), Fish Farming Technology. Balkema, Rotterdam, pp. 85-92.

Munro, P.D., Barbour, A., Birkbeck, T.H., 1994. Comparison of the gut bacterial flora of starting feeding larval turbot reared under different conditions. J. Food Prot. 40, 288.

Munro, P.D., Henderson, R.J., Barbour, A., Birkbeck, T.H., 1999. Partial decontamination of rotifers with ultraviolet radiation: the effect of changes in the bacterial load and flora of rotifers on mortalities in start-feeding larval turbot. Aquaculture 170, 229-244.

Muroga, K., Yasunobu, H., 1987. Uptake of bacteria by rotifer. Bull. Jpn. Soc. Sci. Fish 53, 2091.

Muroga, K., Higashi, M., Keitoku, H., 1987. The isolation of intestinal microflora of farmed red seabream (Pagrus major) and black seabream (Acanthopagrus schlegeli) at larval and juvenile stages. Aquaculture $65,79-88$. 
Nagata, W.D., Hirata, H., 1986. Mariculture in Japan: past, present, and future prospectives. Mini Rev. Data File Fish. Res. 4, 1-38.

Nicolas, J.L., Robic, E., Ansquer, D., 1989. Bacterial flora associated with a trophic chain consisting of micro-algae, rotifers and turbot larvae: influence of bacteria on larval survival. Aquaculture 83, 237-248.

Øie, G., Olsen, Y., 1997. Protein and lipid content of the rotifer Brachionus plicatilis during variable growth and feeding condition. Hydrobiologia 358, 251-258.

Øie, G., Haaland, H., Reitan, K.I., Olsen, Y., 1995. Short-term effects of algal diets on the protein and lipid contents of individual rotifers. Quality in Aquaculture, Aquaculture Europe'95, Trondheim, Norway, pp. $37-39$.

Øie, G., Makridis, P., Reitan, K.I., Olsen, Y., 1997. Survival and utilization of carbon and protein in turbot larvae (Scophthalmus maximus L.) feed rotifers (Brachionus plicatilis) with different protein, lipid and protein/lipid ratio. Aquaculture 153, 103-122.

Olsen, Y., Reitan, K.I., Vadstein, O., 1993. Dependence of temperature on loss rates of rotifers, lipids, and w3 fatty acids in starved Brachionus plicatilis cultures. Hydrobiologia 255-256, 13-20.

Pedersen, B.H., Hjelmeland, K., 1988. Fate of typsin and assimilation efficiency in larval herring (Clupea harengus) following digeston of copepods. Mar. Biol. 97, 467-476.

Pedersen, B.H., Nilssen, E.M., Hjelmeland, K., 1987. Variations in the content of trypsin and trypsinogen in larval herring (Clupea harengus) digesting copepod nauplii. Mar. Biol. 94, 171-181.

Perez-Benavente, G., Gatesoupe, F.J., 1988a. Bacteria associated with cultured rotifers and Artemia are detrimental to larval turbot, Scophthalmus maximus L. Aquacult. Eng. 118, 289-293.

Perez-Benavente, G., Gatesoupe, F.J., 1988b. The continuous distribution of rotifers increases the essential fatty acid reserve of turbot larvae, Scophthalmus maximus. Aquaculture 72, 109-114.

Pianka, E.R., 1970. On r- and K-selection. Am. Nat. 104, 592-597.

Provasoli, L., Shiraishi, K., 1959. Axenic cultivation of the brine shrimp Artemia salina. Biol. Bull. 117, 347-355.

Reitan, K.I., Rainuzzo, J.R., Øie, G., Olsen, Y., 1993. Nutritional effects of algal addition in first feeding of turbot (Scophthalmus maximus) larvae. Aquaculture 118, 257-275.

Reitan, K.I., Rainuzzo, J.R., Olsen, Y., 1994. Influence of lipid composition of live feed on growth, survival and pigmentation of turbot larvae. Aquacult. Int. 2, 33-48.

Rodriguez, J.L., Planas, M., Otero, J.J., 1991. Microflora and antibacterial treatments of rotifers and Artemia. In: Lavens, P., Sorgeloos, P., Jaspers, E., Ollevier, F. (Eds.), Larvi '91—Fish and Crustacean Larviculture Symposium, Gent, Belgium, 27-30 August 1991. Eur. Aqua. Soc., Special Publication 15, pp. 358-360.

Rombaut, G., Dhert, P., Vandenberghe, J., Verschuere, L., Sorgeloos, P., Verstraete, W., 1999. Selection of bacteria enhancing the growth rate of axenically hatched rotifers (Brachionus plicatilis). Aquaculture 176, 195-207.

Salvesen, I., Skjermo, J., Vadstein, O., 1999. Growth of turbot (Scophthalmus maximus L.) during first feeding in relation to the proportion of $\mathrm{r} / \mathrm{K}$-strategists in the bacterial community of the rearing water. Aquaculture 175, 337-350.

Sargent, J.R., Bell, J.G., Bell, M.V., Henderson, R.J., Tocher, D.R., 1995. Requirement criteria for essential fatty acids. J. Appl. Ichthyol. 11, 183-198.

Sargent, J.R., Bell, J.G., McEvoy, L.A., Tocher, D.R., Estévez, A., 1999. The essential fatty acid nutrition of developing fish. Proc. 3rd Symp. On Research in Aquaculture, Barcelona, Spain, 24-27 August 1997 (in press).

Seto, A., Kumasaka, K., Hosaka, M., Kojima, E., Kashiwakura, M., Kato, T., 1992. Production of eicosapentaenoic acid by a marine microalga and its commercial utilization for aquaculture. In: Kyle, D.J., Ratledge, C. (Eds.), Industrial Applications of Single Cell Oils. American Oil Chemists' Society, Champaign, IL, pp. 219-234.

Shiri Harzevilli, A.R., Van Duffel, H., Defoort, T., Sorgeloos, P., Swings, J., 1995. The influence of a selected bacterial strain Vibrio anguillarum TR27 on the growth of the rotifer, Brachionus plicatilis in two culture conditions. In: Lavens, P., Jaspers, E., Roelants, I. (Eds.), Larvi'95-Fish and Shellfish Larviculture Symposium, Eur. Aqua. Soc., Special Publication No. 24, Gent, Belgium, 3-7 September 1995, pp. 480-483.

Shiri Harzevilli, A.R., Van Duffel, H., Defoort, T., Sorgeloos, P., Swings, J., 1997. The influence of a selected 
bacterial strain Vibrio anguillarum TR27 on the growth of the rotifer, Brachionus plicatilis in two culture conditions. Aquacult. Int. 5, 183-188.

Skjermo, J., Vadstein, O., 1993. Characterization of the bacterial flora of mass cultivated Brachionus plicatilis. Hydrobiologia 255-256, 185-191.

Skjermo, J., Vadstein, O., 1999. Techniques for microbial control in the intensive rearing of marine larvae. Aquaculture 177, 333-343.

Skjermo, J., Salvesen, I., Oie, G., Olsen, Y., Vadstein, O., 1997. Microbially matured water: a technique for selection of a non-opportunistic bacterial flora in water that may improve performance of marine larvae. Aquacult. Int. 5, 13-28.

Smith, J., 1991. Probiotics-fact or fiction? J. Chem. Technol. Biotechnol. 51, 539-570.

Snell, T.W., 1991. Improving the design of mass culture systems for the rotifer, Brachionus plicatilis. In: Fulks, W., Main, K.L. (Eds.), Rotifer and Microalgae Culture Systems. Proceeding of US-Asia Workshop, Honolulu, Hawai, Jan. 28-31, pp. 61-71.

St $\varnothing$ ttrup, J.G., Attramadal, Y., 1992. The influence of different rotifer and Artemia enrichment diets on growth, survival and pigmentation in turbot (Scophthalmus maximus L.) larvae. J. World Aquacult. Soc. $23,307-316$.

Suantika, G., Dhert, P., Nurhudah, M., Sorgeloos, P., 2000a. High-density production of the rotifer Brachionus plicatilis in a recirculation system: consideration of water quality, zootechnical and nutritional aspects. Aquacult. Eng. 21, 201-214.

Suantika, G., Dhert, P., De Wolf, T., Sorgeloos, P., 2000b. The use of a recirculation system for rotifer production on a commercial scale. In: Flos, R., Creswell, L. (Eds.), Responsible Aquaculture in the New Millenium. AQUA 2000, Nice, France, May 2-6, 2000. Eur. Aqua. Soc., Special Publication 28, p. 685.

Sukenik, A., Wahnon, R., 1991. Biochemical quality of marine unicellular algae with special emphasis on lipid composition: I. Isochrysis galbana. Aquaculture 97, 61-72.

Sukenik, A., Zmora, O., Carmeli, Y., 1993. Biochemical quality of marine unicellular algae with special emphasis on lipid composition: II. Nannochloropsis sp. J. Aquacult. 117, 313-326.

Tanasomwang, V., Muroga, K., 1989. Effects of sodium nifustyrenate and tetracycline on the bacterial flora of rotifers (Brachionus plicatilis). Fish Pathol. 24, 29-35.

Tanasomwang, V., Muroga, K., 1990. Intestinal microflora of marine fishes at their larval and juvenile stages. In: Hirano, R., Hanyu (Eds.), The 2nd Asian Fisheries Forum. Tokyo, Japan, 17-22 April 1989. Asian Fisheries Society, Manila, Philippines, pp. 647-657.

Tocher, D.R., Sargent, J.R., 1987. The effect of calcium ionophore A23187 on the metabolism of arachidonic and eicosapentaenoic acid in neutrophils from a marine teleost fish rich in (n-3) polyunsaturated fatty acids. Comp. Biochem. Physiol., Part B 67, 733-739.

Ushiro, M., Yamasaki, S., Hirata, I., 1980. Examinations of bacteria as food for Brachionus plicatilis in culture. Min. Rev. Data File Fish. Res. 1, 96-106.

Vadstein, O., Øie, G., Olsen, Y., Salvesen, I., Skjermo, J., 1993. A strategy to obtain microbial control during larval development of marine fish. In: Reinertsen, H., Dahle, L.A., Jorgensen, L., Tvinnereim, K. (Eds.), Fish Farming Technology. Balkema, Rotterdam, pp. 69-75.

Verdonck, L., Dehasque, M., Swings, J., Sorgeloos, P., Leger, P., 1991. The microbial environment of rotifer (Brachionus plicatilis) and Artemia production systems. In: Lavens, P., Sorgeloos, P., Jaspers, E., Ollevier, F. (Eds.), Larvi '91—Fish and Crustacean Larviculture Symposium, Gent, Belgium. Eur. Aqua. Soc., Special Publication 15, p. 398.

Verdonck, L., Grisez, L., Sweetman, E., Minkoff, G., Sorgeloos, P., Ollevier, F., Swings, J., 1997. Vibrios associated with routine productions of Brachionus plicatilis. Aquaculture 149, 203-214.

Verschuere, L., Dhont, J., Sorgeloos, P., Verstraete, W., 1997. Monitoring biolog patterns and r/K-strategists in the intensive culture of Artemia juveniles. J. Appl. Microbiol. 83, 603-612.

Walz, N., Hintze, T., Rusche, R., 1997. Algae and rotifer turbistats: studies on stability of live feed cultures. Hydrobiologia 358, 127-132.

Watanabe, T., 1979. Nutritional quality of living feeds used in seed production of fish. Proc. 7th Japan-Soviet Joint Symp. Aquaculture, Sept. 1978, Tokyo, pp. 49-66.

Watanabe, T., 1993. Importance of docosahexaenoic acid in marine larval fish. J. World Aquacult. Soc. 24, $152-161$. 
Watanabe, T., Kitajima, C., Fujita, S., 1983. Nutritional values of live organisms used in Japan for mass propagation of fish: a review. Aquaculture 34, 115-143.

Whyte, J.N.C., Nagata, W.D., 1990. Carbohydrate and fatty acid composition of the rotifer, Brachionus plicatilis, fed monospecific diets of yeast or phytoplankton. Aquaculture 89, 263-272.

Yasuda, K., Taga, N., 1980. Culture of Brachionus plicatilis Müller using bacteria as food. Nippon Suisan Gakkaishi 46, 933-939.

Yoshimura, K., Miyamoto, Y., Nakamura, T., 1994. High density cultivation of the rotifer, Brachionus plicatilis, by feeding condensed Chlorella. Nippon Suisan Gakkaishi 60, 207-213.

Yoshimura, K., Iwata, T., Tanaka, K., Kitajima, C., Isizaki, F., 1995. A high density cultivation of rotifer in an acidified medium for reducing undissociated ammonia. Nippon Suisan Gakkaishi 61, 602-607.

Yoshimura, K.A., Hagiwara, A., Yoshimatsu, T., Kitajima, C., 1996. Culture technology of marine rotifers and implication for intensive culture of marine fish in Japan. Mar. Freshwater Res. 47, 217-222.

Yoshimura, K., Usuki, K., Yoshimatsu, T., Kitajima, C., Hagiwara, A., 1997a. Recent development of a high density mass culture system for the rotifer Brachionus rotundiformis tschugunoff. Hydrobiologia 358, $139-144$.

Yoshimura, K., Usuki, K., Yoshimatsu, T., Tanaka, K., Ishizaki, A., 1997b. Determination of marine rotifer biomass by centrifugation. Suisan Zoshoku 45, 171-177.

Yoshimura, K., Usuki, K., Yoshimatsu, T., Tanaka, K., Ishizaki, A., 1997c. Quantitative determination and separation of wastes in high density culture medium for marine rotifer. Nippon Suisan Gakkaishi 63, 912-919.

Yu, J.P., Hino, A., Ushiro, M., Maeda, M., 1989. Function of bacteria as vitamin B12-producers during mass culture of the rotifer Brachionus plicatilis. Nippon Suisan Gakkaishi 55, 1799-1806.

Yu, J.P., Hino, A., Noguchi, T., Wakabayashi, H., 1990. Toxicity of Vibrio alginolyticus on the survival of the rotifer Brachionus plicatilis. Nippon Suisan Gakkaishi 56, 1455-1460. 